\title{
EXPLORING GEOCHRONOLOGY: DATING YOUNG LAVA FLOWS AND OLD TREES IN DECLINE
}

Faculty:

MEAGEN POLLOCK, The College of Wooster

GREG WILES, The College of Wooster

\section{Students:}

JOHSUA CHARLTON, The College of Wooster; ALORA CRUZ, Macalester College;

MYRON MALISSE LUMMUS, Trinity University; KERENSA LOADHOLT, Oberlin College;

CHRISTOPHER MESSERICH, Washington and Lee; PA NHIA MOUA, Carleton College;

SAMUEL PATZKOWSKY, Franklin and Marshall; EMILY RANDALL, The College of Wooster;

MADISON LILITH ROSEN, Mount Holyoke; ADDISON THOMPSON, Pitzer College

\section{INTRODUCTION}

In the summer of 2017,10 students participated in a 5-week Gateway project hosted at The College of Wooster (Figure 1). Students conducted research in two teams led by co-directors Meagen Pollock and Greg Wiles. Team Utah (led by Pollock) investigated the age of young basaltic lava flows in Utah's Ice Springs Volcanic Field (ISVF). The goals of the Utah project were to constrain the timing of ISVF volcanism relative to the development of the Black Rock Desert (BRD), revise the lava flow emplacement history, and test the classification of the ISVF as a polymagmatic compound monogenetic field. Team Alaska (led by Wiles) reconstructed the growth history and recent climate response of yellow-cedar in Juneau, Alaska. The goals of the Alaska project were to sample tree-ring sites along elevational transects in the Juneau region and develop chronologies (ring-width and Blue Intensity (BI) records) to compare these records with meteorological records from stations along the Gulf of Alaska and with gridded data from the North Pacific. These comparisons allow us to better understand the forest decline in the region.
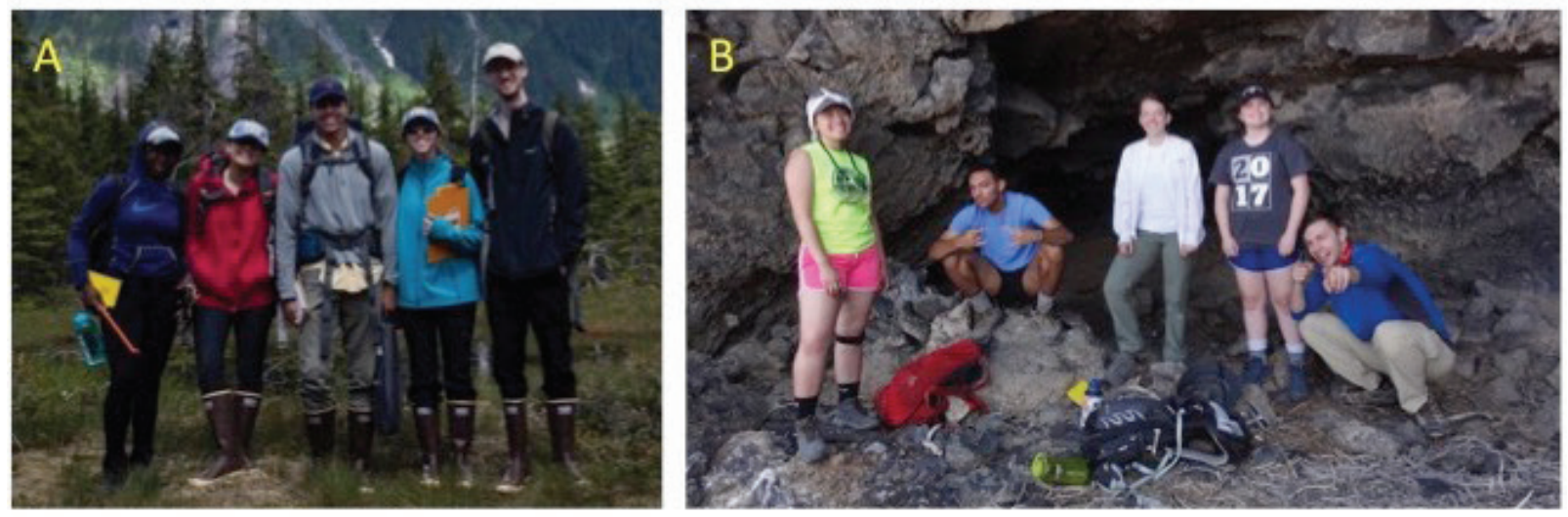

Figure 1. (a) Team Alaska. From left to right: Kerensa Loadholt, Alora Cruz, Chris Messerich, Malisse Lummus, and Josh Charlton. (b) Team Utah. From left to right: Pa Nhia Moua, Addison Thompson, Emily Randall, Madison Rosen, and Sam Patzkowsky. 
Both projects began at Wooster, where the groups learned how to core trees and describe samples in preparation for field work. The teams then went to their respective field sites, where they collected data and interacted with professional geoscientists. The students shared their experiences on the Wooster Geologists blog and highlights included visits to the Alaska State Museum and the Utah Core Repository. When the teams returned to Wooster, they embarked on the analytical component of the research project. For the Utah project, students prepared samples for geochemical analysis by X-ray Fluorescence (XRF) in Wooster's X-ray lab and sent samples to external labs for trace element analysis. Students also prepared samples for bulk $36 \mathrm{Cl}$ analysis at the Purdue PRIME lab and used previous cosmogenic data with the CRONUS Earth Web Calculator to estimate an age for ISVF. For the Alaska project, students collected ringwidth and BI time series records in the Wooster Tree Ring Lab. The tree-ring chronologies were compared with station climate data from the Juneau area and with a variety of gridded climate records available on Climate Explorer.

The teams achieved their research objectives and presented their work at the 2017 GSA annual meeting in Seattle, Washington. Team Utah's poster was titled New Cosmogenic and VML Dates and Revised Emplacement History of the Ice Springs Volcanic Field in the Black Rock Desert, Utah (Patzkowsky et al., 2017). Team Alaska's poster was titled Yellow Cedar Growth Response to Decadal Climatic Shifts at Cedar Lake, Juneau, Alaska (Charlton et al., 2017). Their GSA posters can be found on the Keck Geology Consortium website. This short contribution summarizes their work and highlights their key findings.

\section{ICE SPRINGS VOLCANIC FIELD, BLACK ROCK DESERT, UTAH}

Utah's Black Rock Desert (BRD), located in the Basin \& Range Province, contains 7+ unique volcanic fields, all $1 \mathrm{Ma}$ or younger (Condie and Barsky, 1972). Ice Springs Volcanic Field (ISVF) is one of youngest BRD units, dated at $660 \pm 170$ years ago (Figure 2, Valestro et al., 1972). ISVF is hypothesized to be a compound polygenetic volcano due to multiple cinder cones (Miter, Terrace, Pocket, \& Crescent), eruptions, and magma batches (Nemeth and Kereszturi, 2015;

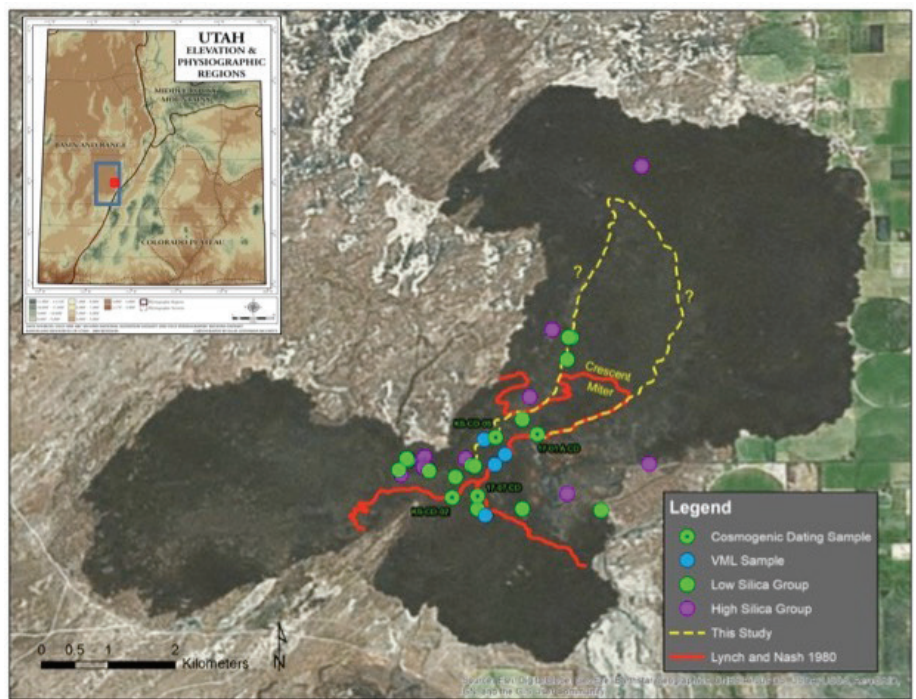

Figure 2. Map of Ice Springs Volcanic Field. Circles show locations of low silica (green) and high silica (purple) samples. $V M L$ (blue) and cosmogenic dating (dot) samples are located in the area west of the cones. Boundaries of Lynch and Nash (1980) are in red. Proposed boundaries from this study are in yellow. Inset map shows location of Ice Springs Volcanic Field (red square) in Utah's Black Rock Desert (blue rectangle).

Williams, 2016). Individual flows boundaries have been previously defined (Gilbert, 1890; Hoover, 1974; Lynch and Nash, 1980), but have been called into question based on recent mapping and geochemical analysis (Figure 2, Thompson, 2009; Sims, 2013). The development of robust dating methods (Cosmogenic Dating \& Varnish Microlamination (VML)) makes it possible to more accurately determine the date of young lava flows in the ISVF. This study aims to determine the flows' emplacement sequence and ages in order to place the ISVF in geologic context and improve understanding of its eruption history.

Our approach combines mapping and geochemical investigations with multiple dating techniques. Eight samples from the Miter and Crescent flows were collected for major element geochemical analysis by XRF at The College of Wooster. Two additional pahoehoe samples were collected from the Miter/ Terrace boundary and within the Miter flow for cosmogenic 36Cl dating at the Purdue PRIME lab. The CRONUS calculator (Marrero et al., 2015) was used to find minimum and maximum ages for the lava flows based on variations in erosion rates, density, and scaling framework. VML ultra-thin thin sections (Goldsmith, 2011; Liu and Broecker, 2013) were 
made from samples of the Miter/Terrace flows to independently estimate the age.

Age estimates from VML and cosmogenic $36 \mathrm{Cl}$ methods are approximately the same and significantly older than previous estimates (Figure 3). Two VML samples yielded the oldest dates of $\sim 12,500$ years, based on distinct layering that could be correlated to established VML stratigraphy in the western U.S. (Figure 3a, Liu and Broecker, 2013). The 36Cl age range of the sample from the Miter/Terrace boundary $(\mathrm{CD}-02)$ is $9.4( \pm 1.3)$ to $10.9( \pm 1.6) \mathrm{kyr}$. The $36 \mathrm{Cl}$ age range for the Miter flow (CD-05) is $10.9( \pm 1.6)$ to $11.3( \pm 1.5) \mathrm{kyr}$ (Figure $3 \mathrm{~b})$. Our cosmogenic age ranges for ISVF are significantly older than those previously found by Valastro et al. (1972; $660 \pm 170$ years) and Hoover (1974; 1 - 4 kyr), but are still viable as they would have been post Lake Bonneville at an elevation of $\sim 1,400 \mathrm{~m}$ (Figure 3b, Lifton et al., 2015).

Our mapping and geochemical analyses also disagree with previous observations (Figures 2 and 3c). Two previously identified ISVF compositional groups are distinct in major and trace elements, and are referred to as "high silica" and "low silica" lava flows (Lynch \& Nash, 1980; Nelson \& Tingey, 1997; Thompson, 2009; Sims, 2013; Matesich, 2014). High silica lavas are correlated with the oldest lava flows, originating from Crescent. Low silica lavas correlate with the Miter and Terrace eruptions. Samples from this study that are currently mapped at Miter overlap with Crescent flows; those that are currently mapped as Crescent overlap with Miter and Terrace flows (Figure 3c). The new geochemical data suggest that the previous boundary between the Miter and Crescent flows is either not in the correct location or that the chemistry of the Crescent flow is much more complex than previously thought. We propose a new Miter/ Crescent boundary based on geochemistry (Figure 2).

In summary, new cosmogenic dates for the ISVF range from $9.4( \pm 1.3)$ - $11.3( \pm 1.5) \mathrm{kyr}$, similar to VML ages of $\sim 12.5 \mathrm{kyr}$. These ages are much older than previous estimates, but still consistent with the geologic history of the BRD and Lake Bonneville. Additional geochemical data fill gaps in previous sampling and suggest newly mapped boundaries between the Crescent and Miter lava flows. The ages of ISVF flows and its multiple eruptions support its
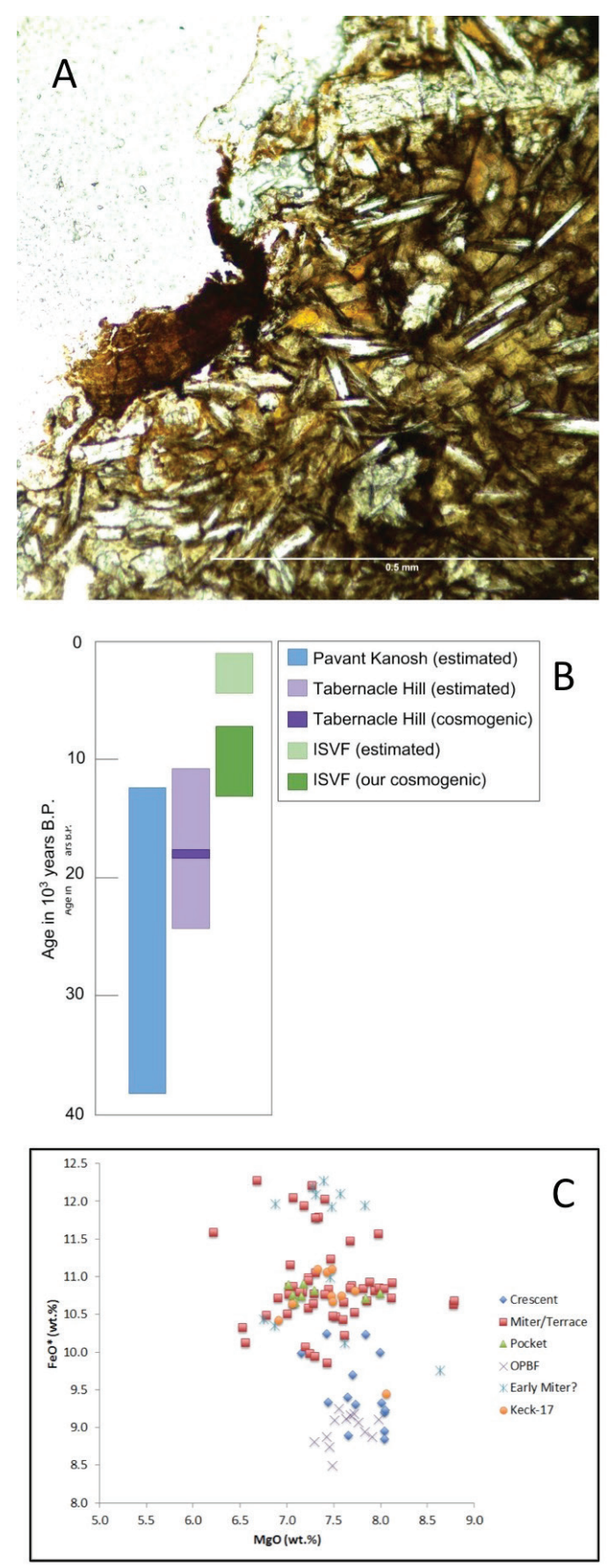

Figure 3. (a) VML sample yields a date of $\sim 12,500$ as indicated by the distinct layering and representation of layer WP0 (from Liu and Broecker, 2013) at the base. (b) Our cosmogenic age range for ISVF (dark green) in relation to the Pavant Kanosh estimated age (blue; Condie and Barsky, 1972), Tabernacle Hill estimated age (light purple; Condie and Barsky, 1972; Hoover, 1974), Tabernacle Hill cosmogenic age (dark purple; Lifton et al., 2015), and ISVF estimated age (light green, Hoover, 1974). (c) $\mathrm{FeO}^{*}$ vs. $\mathrm{MgO}$ (in wt.\%) for ISVF. Crescent flows show low $\mathrm{FeO}$ * compared to Miter and Terrace. Samples from this study that are currently mapped as Miter (OPBF and one Keck-17) overlap with Crescent flows; those that are currently mapped as Crescent (Keck-17) overlap with Miter and Terrace flows. Previous geochemistry from Lynch and Nash, 1980; Nelson and Tingey, 1997; Thompson, 2009; and Matesich, 2014. 
classification as a compound polygenetic volcano according to the Nemeth and Kereszturi (2015). Additional ages and geochemical sampling can clarify details of the eruption history of an area of local importance for its economic mining operations and potential for geothermal energy development.

\section{YELLOW CEDAR, JUNEAU, ALASKA}

The decline of yellow-cedar (Callitropsis nootkatensis D. Don; Oerst. Ex D.P. Little) is an ongoing forest response to climate change that has been linked to warming temperatures, earlier snow melt, and a transition of snow to rain, which all lead to a loss of snowpack. Snow protects vulnerable small roots of this shallow-rooting species and thus the trees are more susceptible to frost damage (Shaberg et al., 2011; Hennon et al. 2012, 2016). Extensive work, testing this hypothesis is underway, in part, driven by consideration of listing the species as endangered (Bidlack et al., 2017; Buma et al., 2017).

We examined the climate response of a well-replicated composite tree-ring chronology from three sites in the Juneau, Alaska region (Figure 4). Ring-widths (RW) and latewood blue intensity measurements (LBi) were measured, developed into tree ring series, and the climate response was analyzed in this region where snowfall is decreasing as temperature and rainfall increase. $\mathrm{LBi}$ is a proxy for maximum latewood density and is a less expensive alternative (Björklund et al., 2014; Wilson et al., 2017). We present the RW and LBi records and examine their potential for climate reconstruction and interpret results in the context of the yellow-cedar decline.

Trees were cored at the three sites (Figure 4). Increment cores were mounted on sticks and sanded to a high polish, scanned as high-resolution image files, and analyzed using CDendro 8.1 and CooRecorder 8.1. The final combined RW and LBi chronologies incorporate 179 series from 113 trees and we examined the record back to CE 1400 where the series are sufficiently replicated (Figure $5 c$ ).

The two chronologies were correlated with monthly maximum average temperatures within the coordinates 57 o-62o N, 130 o -140o W (Harris et al., 2014; Figure $5 b)$ for the CE 1900-2014 interval. For precipitation,

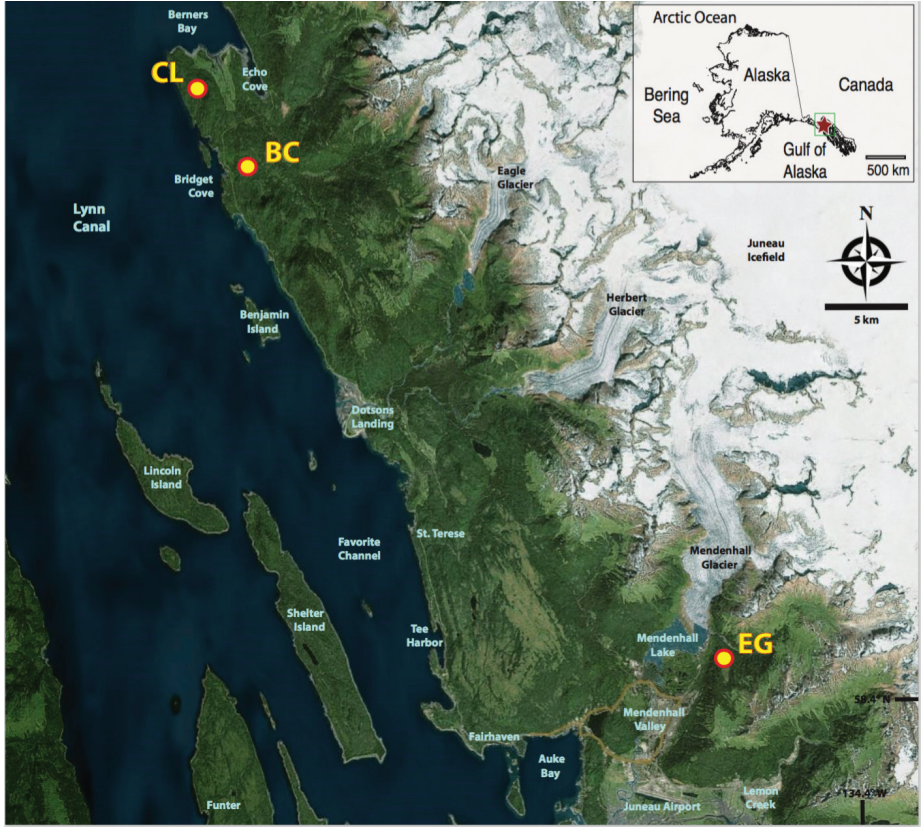

Figure 4. Map of the three yellow cedar tree-ring sites near Juneau, Alaska. CL-Cedar Lake, BC-Bridget Cove, and $E G-$ East Glacier. The ring-width and latewood blue intensity chronology for this study were generated from a composite from the three sites. The box in the inset location map outlines the region from which temperature records were averaged.

we assembled the monthly Juneau total precipitation records for 1949-2014 extracted from Climate Explorer (Trouet and Oldenborgh, 2013).

The RW and LBi series shows strong synchronous decadal variability throughout the record (CE 14001975) until they diverge notably after about 1975 (Figure 5a), when the LBi record decreases and the RW series drops, and then generally increases through recent decades. Climate comparisons were made for the standard dendroclimatic year that consisted of March through December of the previous year of growth and January through October of the year of growth (not shown). The RW series did not show a strong climate response and is not considered further. For the $\mathrm{LBi}$, the strongest correlation was with January-August maximum mean temperature (Figure $5 b$ ), which correlates at 0.62 for the interval 1902$1975(p<0.00001)$. We identified a marked decrease in correlation after 1976 (Figure 5b) and then a recovery in correlation in the recent decades.

For precipitation, we correlated monthly totals with the LBi series (Figure $5 \mathrm{c}$ ) for the early period from 1949-1975; there were no significant correlations at 
the $95 \%$ confidence levels for this interval. However, for the interval after 1975, there is a strong negative relationship with the LBi and with total JulySeptember precipitation (Figure 5c). This observation suggests that high rainfall during these late summer months into the early fall is detrimental to tree growth.

In contrast with the temperature response, which shows a recovery from negative to positive correlation after about 2001 (Figure 5b), the precipitation response remains negative (Figure 5c).
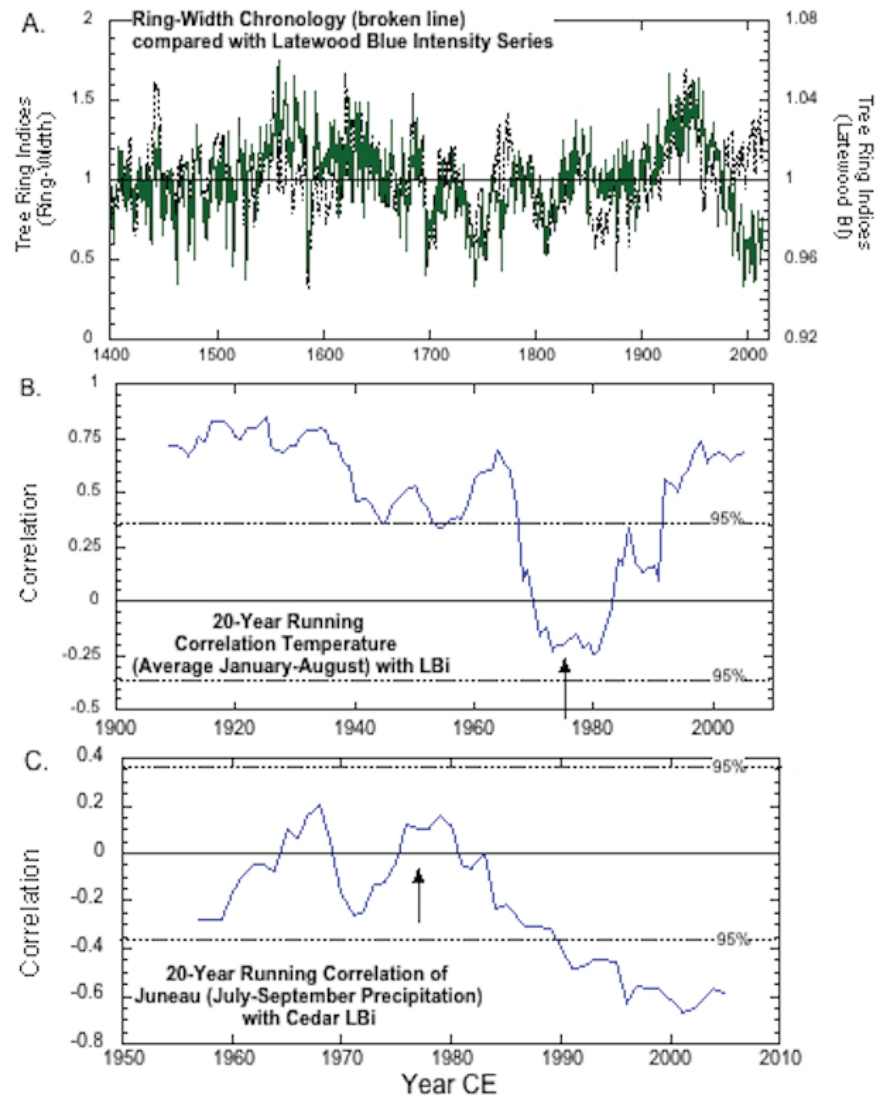

Figure 5. (a) Ring-width series compared with the latewood blue intensity chronology, note how the two series diverge after the mid 1970s. (b) 20-year running correlations between average maximum temperatures for January through August with the latewood blue intensity (LBi) record. Up until the mid-1970s regime shift (arrow) in the North Pacific the LBi and temperature records are strongly correlated. After the shift in temperature associated with the regime shift the LBi loses its temperature sensitivity and appears to recover in recent decades. (c) Total July through September precipitation records compared with the LBi record. Here the 20-year running correlation shows a negative relationship beginning on the 1980s and persisting through recent decades.
This study is the first to generate and analyze the climate signal in Blue Intensity chronologies from Alaska yellow-cedar. The well-replicated LBi chronology shows a much stronger sensitivity to temperature than ring-width and furthermore, the BI records from this species are sufficiently sensitive to be an important species in dendroclimatology.

The LBi record however, indicates a nonstationarity in climate response after the well-documented 197677 climate shift. This shift in southeast Alaska forced warmer temperatures, less snow and more rain to the region. Comparisons of monthly climate records with the well-replicated LBiI chronology show a strong positive January-August average temperature signal becoming negative after 1976 with some recovery to a positive response in recent decades. This observation is consistent with previous work on climate response of yellow cedar and the associated cedar decline forced by warming temperatures causing this shallowrooting species to be vulnerable to rootlets freezing as a leading hypothesis for the loss of trees at some sites. In addition to the changes in temperature response, warm-season precipitation (total July-September) increases are linked to negative excursions in the latewood BI suggesting that this parameter may also be sensitive to moisture variability.

\section{CONCLUSIONS}

Ten Gateway students conducted cutting-edge geochronological research, making original intellectual contributions to the fields of volcanology and dendrochronology. Team Utah applied cosmogenic and varnish microlamination dating methods to investigate the emplacement history of Ice Springs Volcanic Field in the Black Rock Desert, Utah. They determined that Ice Springs Volcanic field is significantly older ( $\sim 10 \mathrm{ka})$ than previous estimates. Their work resulted in revised lava flow boundaries and emplacement history for the Ice Springs Volcanic Field, enhancing the understanding of a local area of economic interest for its quarrying and potential to provide geothermal energy. Team Alaska applied dendrochronological methods to investigate the decline of yellow cedar in Cedar Lake north of Juneau, Alaska. Their study is the first to generate and analyze the climate signal in Blue Intensity (BI) chronologies from Alaska yellow-cedar. Their findings support 
the leading hypothesis for cedar decline and provide well replicated ring-width and BI records for further research. Environmental changes in the region are proceeding rapidly and their contribution provides a case study to understand how yellow-cedar and other species may respond to rapid climate change.

\section{ACKNOWLEDGEMENTS}

This material is based upon work supported by the Keck Geology Consortium and the National Science Foundation under Grant No. 1659322. Additional funding was provided by The College of Wooster Wengerd Fund and NSF-AGS-1502186. Thanks to Red Dome Quarry, who owns ISVF and gave us permission to access their land during this research. We appreciate the assistance of Brian Buma, John Krapek, and the Department of Natural Resources at the University of Alaska Southeast. Thanks to Shelley Judge for critical feedback on our project and to Patrice Reeder and Nick Wiesenberg for technical support.

\section{REFERENCES}

Bidlack, A., Bisbing, S., Buma, B., D’Amore, D., Hennon, P., Heutte, T., Krapek, J., Mulvey, R., and Oakes, L., 2017, Alternative interpretation and scale-based context for "No evidence of recent (1995-2013) decrease of yellow-cedar in Alaska" (Barrett and Pattison 2017): Canadian Journal of Forest Research, 2017, v. 47, p. 1145-1151.

Björklund, J. A., Gunnarson, B. E., Seftigen, K., Esper, J., and Linderholm, H. W., 2014, Blue intensity and density from northern Fennoscandian tree rings, exploring the potential to improve summer temperature reconstructions with earlywood information: Climate of the Past, v. 10, p. 877-885, https://doi.org/10.5194/cp-10877-2014.
Buma B, Hennon PE, Harrington CA, Popkin JR, Krapek J, Lamb MS, Oakes LE, Saunders S, Zeglen S. 2017, Emerging climate-driven disturbance processes: widespread mortality associated with snow-to-rain transitions across $10^{\circ}$ of latitude and half the range of a climatethreatened conifer. Global Change Biol. v. 23, p. 2903-2914.

Charlton, J., Cruz, A.J., Lummus, M.M., Loadholt, K., Messerich, C., Wiles, G., Buma, B., and Krapek, J., 2017, Yellow cedar growth response to decadal climatic shifts at Cedar Lake, Juneau, Alaska: GSA Abstracts with Programs, V. 49(6), doi: 10.1130/abs/2017AM-298740.

Condie, K.C., and Barsky, C.K., 1972, Origin of Quaternary basalts from the Black Rock desert region, Utah: Geological Society of America Bulletin, v. 83, p. 333-352.

Gilbert, G.K., 1890, Lake Bonneville: United States Geological Survey, monograph 1, 438 p.

Goldsmith Y., 2011, Characterizing rock varnish developed on earliest Holocene Negev flint artifacts as a potential paleoenvironmental or paleoclimatic indicator: The Hebrew University, Jerusalem, report GSI/33/2011.

Harris, I. P. D. J., Jones, P. D., Osborn, T. J., and Lister, D. H., 2014, Updated high-resolution grids of monthly climatic observations - the CRU TS3. 10 Dataset: Int. J. Climatol., v. 34, p. 623-642.

Hennon, P. E., D'Amore, D. V., Schaberg, P. G., Wittwer, D. T., \& Shanley, C. S., 2012, Shifting climate, altered niche, and a dynamic conservation strategy for yellow-cedar in the North Pacific coastal rainforest: BioScience, v. 62, p. 147-158.

Hennon, P. E., McKenzie, C. M., D’Amore, D., Wittwer, D. T., Mulvey, R. L., Lamb, M. S., Cronn, R. C., 2016, A climate adaptation strategy for conservation and management of yellowcedar in Alaska: PNW-GTR-917. Portland, Oregon, USA: US Department of Agriculture, Forest Service, Pacific Northwest Research Station.

Hoover, J.D., 1974, Periodic Quaternary volcanism in the Black Rock Desert, Utah: Brigham Young University, $70 \mathrm{p}$. 
Lifton, N., Caffee, M., Finkel, R., Marrero, Shasta., Nishiizumi, K., Phillips, F.M.,Goehring, B., Gosse, J., Stone, J., Schaefer, J., Theriault, B., Timothy Jull, A.J., Fifield, K. 2014, In situ cosmogenic nuclide production rate calibration for the CRONUS-Earth project from Lake Bonneville, Utah, -shoreline features: Quaternary Geochronology, 26, 56-69, doi: 10.1016/j. quageo.2014.11.002

Liu, T and Broecker, W.S., 2013, Millennialscale varnish microlamination dating of late Pleistocene geomorphic features in the drylands of western USA: Geomorphology, 187, 38-60.

Lynch, W.C., and Nash, W.P., 1980, Chemical trends in the Ice Springs Basalt, Black Rock Desert, Utah: U.S. Government Documents (Utah Regional Depository), 86 p.

Marrero, S.M., Phillips, F.M., Borchers B., Lifton N., Aumer R., Blaco G., 2015, Cosmogenic Nuclide Systematics and the CRONUScalc Program: Quaternary Geochronology.

Matesich, C., 2014, Geochemical Analysis of Basalt Flows from Miter Crater in Ice Springs Volcanic Field, Utah: [Undergraduate Thesis] The College of Wooster.

Nelson, S. T., and Tingey, D. G., 1997, Timetransgressive and extension-related basaltic volcanism in southwest Utah and vicinity: Geological Society of America Bulletin, 109(10), 1249-1265.

Németh, K., and Kereszturi, G., 2015, Monogenetic volcanism: personal views and discussion: International Journal of Earth Science, 21312146.

Patzkowsky, S., Randall, E., Rosen, M.L., Thompson, A., Moua, P.N., Schantz, K., Pollock, M., Judge, S.A., Williams, M., and Matesich, C., 2017, New cosmogenic and VML dates and revised emplacement history of the Ice Springs Volcanic Field in the Black Rock Desert, Utah: GSA Abstracts with Programs, v. 49(6), doi: 10.1130/ abs/2017AM-306786.

Schaberg, P. G., D’Amore, D. V., Hennon, P. E., Halman, J. M., \& Hawley, G. J., 2011, Do limited cold tolerance and shallow depth of roots contribute to yellow-cedar decline?: Forest Ecology and Management, v. 262,p. 2142-2150.
Sims, W., 2013, Geochemical and geospatial analysis: Mapping of Miter's lava flows in Ice Springs Volcanic Field, Black Rock Desert, Utah: [Undergraduate Thesis] The College of Wooster.

Thompson, J., 2009, Crustal assimilation mechanisms in continental basalts: the Ice Springs flow, Utah: University of Iowa, $203 \mathrm{p}$.

Trouet, V., Van Oldenborgh, J., 2013, KNMI Climate Explorer: A Web-Based Research Tool for High-Resolution Paleoclimatology: Tree-Ring Research v. 69, p. 3-13. DOI:10.3959/1536-109869.1.3

Valastro, S., Davis, E.M., and Varela, A.G., 1972, University of Texas at Austin radiocarbon dates, IX: Radiocarbon, v. 14, p. 461-485.

Williams, M., 2016, Emplacement processes and monogenetic classification of Ice Springs Volcanic Field, central Utah: [Undergraduate Thesis] The College of Wooster.

Wilson, R., D’Arrigo, R., Andreu-Hayles, L., Oelkers, R., Wiles, G., Anchukaitis, K., and Davi, N., 2017, Experiments based on blue intensity for reconstructing North Pacific temperatures along the Gulf of Alaska: Climate of the Past, v. 13, p. 1007-1022, https://doi.org/10.5194/cp-131007-2017. 